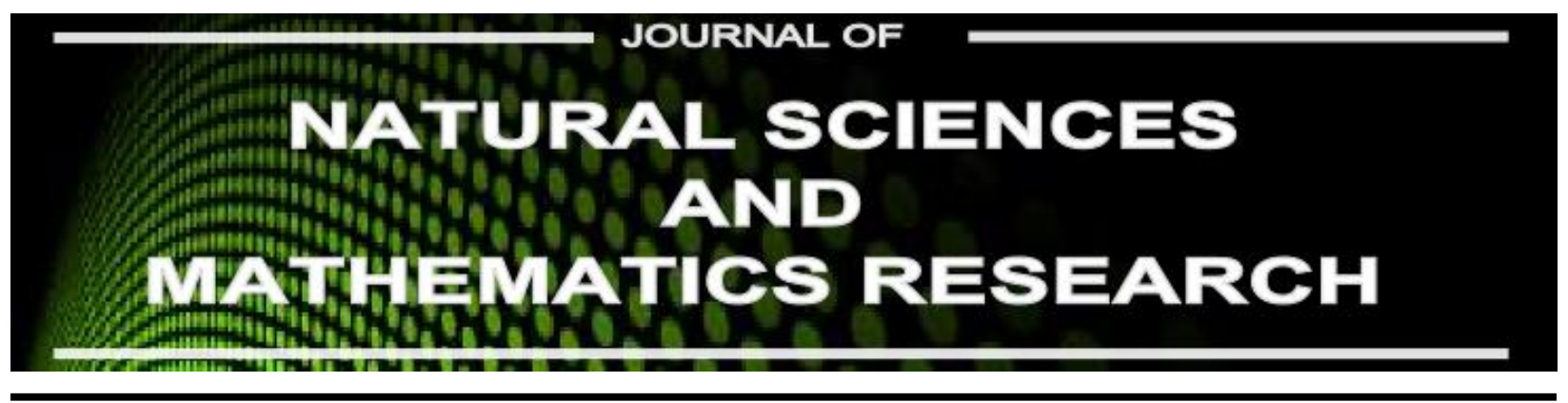

Available online at http://journal.walisongo.ac.id/index.php/jnsmr

\title{
Quality of Yeast Extract of Industry Yeast Press Alcohol waste as Drying result with Various Temperature Variation
}

\author{
G. Maria Yusta, V. Irene Meitiniarti, E.B.E. Kristiani \\ Faculty of Biology,Universitas Kristen Satya Wacana, Central Java, Indonesia
}

\begin{abstract}
s
Corresponding author: The content of yeast in industrial solid waste fermented beverages, has not been irene_meiti@yahoo.com

Recived: 20 November 2016, Revised : 20 December 2016 Accepted: 30 December 2016. widely noticed and utilized, whereas many sources of nitrogen, vitamins and minerals are still present in this yeast. One of the utilization of waste yeast is processed into autolysis yeast extract. The drying process is often done using a spray dryer, but the process is costly so it is not efficient. In this study, we want to determine the temperature and drying time appropriate for maintain of yeast extract quality of yeast press. From this research, we concluded that a drying oven at $60^{\circ} \mathrm{C}$ for 6 hours is drying which does not damage the nutrient (protein, vitamine B2, carbohydrate, prolin, and lysin content) in yeast extract.(C2016 JNSMR UIN Walisongo. All rights reserved.
\end{abstract}

Keywords: Yeast Press; Drying Temperature; Nutrient Quality.

\section{Introduction}

The development of various industries is in great quantities and not localized its give big impact toward surroundings quality. One of the example is little industry of fermentation beverage. Industry of fermentation beverage in small scale, generally spread the location and waste that produced is directly throw away to the water or waste canal of domestic waste. The entry of waste water which is not processed first can polluted river water so it can reduce water quality [1].

Production process of fermentation beverage in small industry is rely on yeast service to produced alcoholic beverage as product and waste in the form of solid or liquid. Industry of beer production used yeast to change sugar become alcohol and $\mathrm{CO}_{2}$ [2]. Yeast usually used repeatedly until several generation (usually 6 generation). In the end of the fermentation with sixth generation of yeast, yeast that is no used will throw away from the tank. Yeast that throw away then will be pressed and throw as solid waste [3]. Yeast is good protein source with content of yeast rough protein range from $45-55 \%$, it depend on strain and development condition [4].

Waste processing at industry of fermentation beverage, especially solid waste 
that contain yeast it appear not pay attention yet. A big part of the waste is throw away without exploiting or processing. In great quantities of nitrogen source, vitamin, and mineral that is in yeast will be useless if its not used continued. One of the used of yeast waste is process to be autolysis yeast extract. Drainage process that usually used in "finishing" phase from yeast extract is used spray dryer [6]. The overbalance of spray dryer is keep nutrient quality inside the material, however spray dryer usage need big enough cost so is not efficient. Because of that, this research is done to search alternative process of other drainage which is not expensive and damage the nutrient quality inside the material.

Based on background above, the purpose of the research is to know the influence of "temperature variation of drainage $40^{\circ} \mathrm{C}, 50^{\circ} \mathrm{C}$, $60^{\circ} \mathrm{C}, 70^{\circ} \mathrm{C}$, freeze dryer' toward quality of yeast extract from yeast press waste seen from content of protein, prolin, lysin, carbohydrate, and vitamin B2 (Ribovlavin).

\section{Experiments Procedure}

\section{Material and Instrument}

Material used in this research is solid waste that taken from ethanol industry at Soka Housing, Salatiga used covered bucket to relieve the other microbe contamination in travel time. The instrument used Erlenmeyer, petri cup, beaker glass, gourd measure, pipette measure, pipette drop, autoklaf, analytic weight, penggojog, hot plate, $\mathrm{pH}$ meter, reaction tube, spectrometer.

Preparation of yeast sample from yeast press waste and autolysis

Autolysis process of yeast cell is started with precipitate biomassa of yeast cell that obtain by precipitate the solid waste used imholf tube. After gained sediment as many as half of the imholf tube, supernatan is throw away. Sediment is washed with added $50 \mathrm{ml}$ aquades. This washing is done twice to get clean yeast biomassa. After gained biomassa, as many as $150 \mathrm{~g}$ biomassa is entered to erlenmeyer, then add $20 \mathrm{ml}$ aquades and arrange the $\mathrm{Ph}$ to 7 by add baking soda. And then, the sample is shaken with speed $100 \mathrm{rpm}$ as long as 6 days so that yeast experience autolysis. After cell experience autolysis, cell is dried according to treatment to be powder of yeast extract. Dried treatment used oven with temperature $40^{\circ} \mathrm{C}, 50^{\circ} \mathrm{C}, 60^{\circ} \mathrm{C}, 70^{\circ} \mathrm{C}$ and freeze dryer to dried without used heat. On dried treatment used oven, it is done withdrawal sample every 6 hours interval time started $0^{\text {th }}$ hour until yeast extract is dry. In every sample is done measure content of protein, carbohydrate, vitamin b2 (riboflavin), prolin, and lysin. Control material used in this research is yeast extract with MERCK brand.

Quality Analysis of Yeast extract

Quality parameter of yeast extract that determine is protein contentwith Biuret method [6], vitamin $B_{2}$ with spektrofotometrik [7], contain of carbohydrate with DNS method [8], prolin according Bates [9], and lysin with spektrofotometrik [10].

\section{Results and Discussion}

Beginning character of solid waste of ethanol industry that will be extracted have light brown color (Figure 1.a) at temperature $28^{\circ} \mathrm{C}$ and $\mathrm{pH} 4,7$. After added baking soda for autolysis process, yeast waste become gray color, and after experience autolysis, yeast waste become black dark brown color (Figure 1.b).

Final result of yeast extract that is dried have black dark brown color in all variation in dried temperature (Figure 2.a,b,c, and d). While yeast extract which dried with freeze dryer have gray brown color (Figure 2.e). Differentiation color on final result of yeast extract might be influenced by drying process and based material from yeast growth medium. Based on the result, yeast extract is dried used oven have more dark color than dried used freeze dryer. Final result of yeast extract color after dried with various drying is not same with yeast 
extract (MERCK brand) which have yellow color.

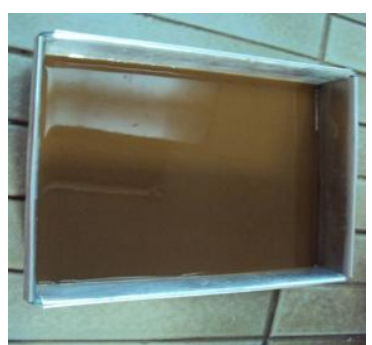

(a)

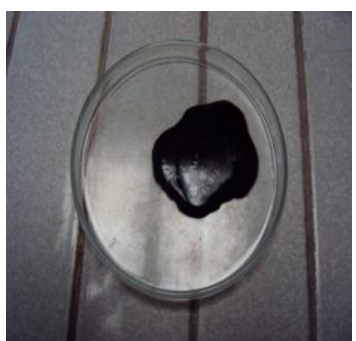

(b)
Figure 1. Appearance of beginning yeast waste (a) and after autolysis (b)

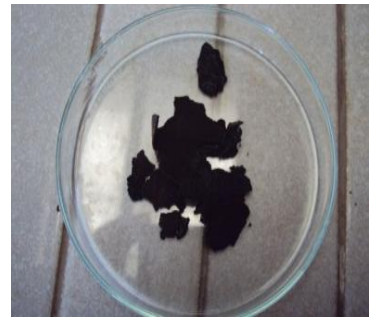

(a)

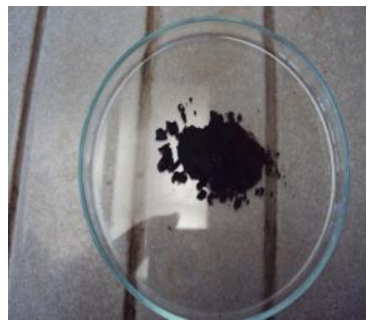

(c)

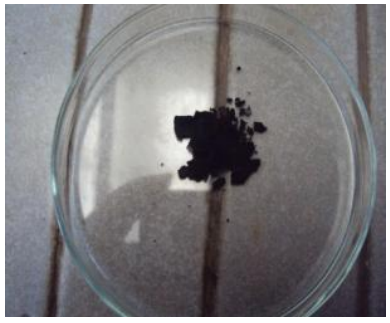

(b)

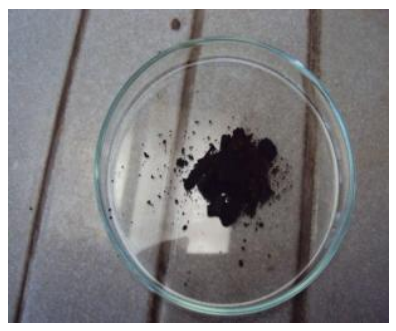

(d)

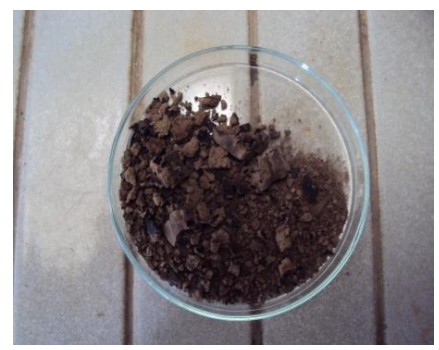

(e)

Figure 2 Yeast extract after dried with temperature $40^{\circ} \mathrm{C}(\mathrm{a}), 50^{\circ} \mathrm{C}(\mathrm{b}), 60^{\circ} \mathrm{C}(\mathrm{c}), 70^{\circ} \mathrm{C}(\mathrm{d})$, and dried with freeze-dryer $(\mathrm{e})$

Color differentiation of yeast extract might influenced by differentiation of medium of fermentation process in every industry, so produced various color of yeast biomassa from every ethanol industry. Yeast biomassa used to made yeast extract can used solid waste from alcohol fermentation process or special yeast that growth to produce biomassa. Yeast biomassa which gain from side result of alcohol production process have different color based on the material that used to fermentation, beside that medium used to yeast which growth to produce biomassa also different from medium to produce alcohol. Medium differentiation might be influence the color of yeast extract that is produced.

Based on result, protein value experience increase until $30^{\text {th }}$ hour at dry temperature $40^{\circ} \mathrm{C}$, after that experience decrease. While, yeast extract that dried at temperature $50^{\circ} \mathrm{C}$ and $60^{\circ} \mathrm{C}$ take place increasing protein value on $6^{\text {th }}$ hour, however the value is continue stable until $30^{\text {th }}$ hour. After that protein value experience decrease. In yeast extract that dried at temperature $70^{\circ} \mathrm{C}$, after $6^{\text {th }}$ hour the protein value is continue experience decrease (picture 3). Decrease of protein value is because the high temperature take place protein denaturation so the protein content after $30^{\text {th }}$ hour will decrease. In autolysis process, temperature and $\mathrm{pH}$ should be controlled so that it can damage the yeast quality, because in acid $\mathrm{pH}$ and high temperature it can decrease the quality of yeast extract, because the yeast protein will be damage [11].

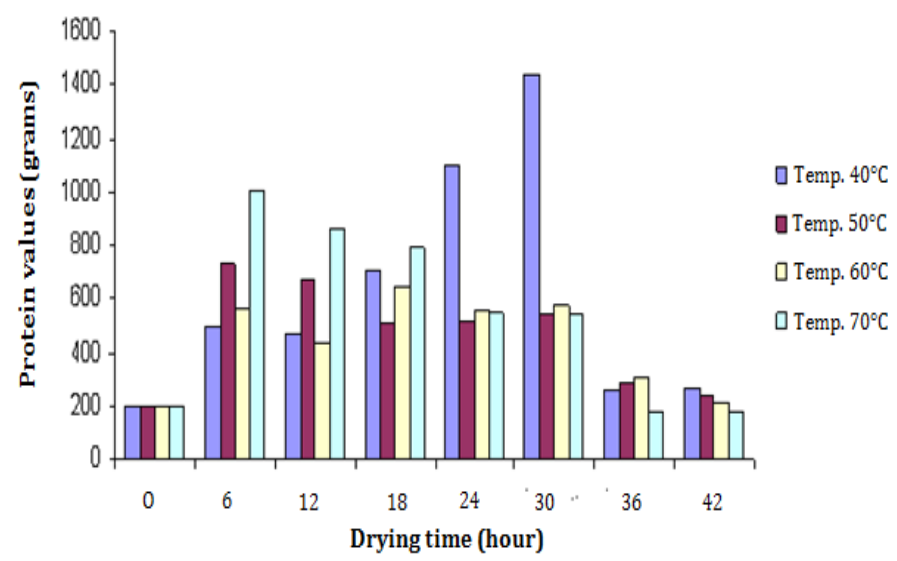

Figure 3. Protein value at various temperature of even drying

Based on research result, carbohydrate value on yeast extract that is dried in 
temperature $50^{\circ} \mathrm{C}, \quad 60^{\circ} \mathrm{C}$, and $70^{\circ} \mathrm{C}$ continually decline after $6^{\text {th }}$ hour (Picture 4). while yeast extract that dried in temperature $40^{\circ} \mathrm{C}$ continually increase until $30^{\text {th }}$ hour, after $30^{\text {th }}$ hour the carbohydrate value decline. The descent of carbohydrate value is happen because of carbohydrate faced Maillard reaction and the color change become dark brown [12].

The first phase of Maillard reaction is condensation between $\alpha$-amino from amino acid or protein with carbon cluster from reduction sugar. This phase called carbonilamo reaction and first product will lost water, form Schiff alkali followed with siklisation produce glycosilamin that $\mathrm{N}$ substitute. This compound is very unstable so experience isomerasi become fruktosamino acid (1-amino-1-deoksi-1ketosa). This reaction called Amadori rearrangement. The next phase, at least 3 strip of form of melanoidin brown color in Maillard reaction. First, through Amadori compound that change become 1.2eneaminol and 2.3-enediol. Second, aldol condensation that is alternative strip. Third, Streckeri that is indirectly form pigment but also supply important compound as reducing agent to form brown color [13].

First phase of Maillard reaction, the existence of sugar as reducing agent is very important because it supply the carbon cluster to interaction with free amino and amino acid, peptida or protein. First reaction rapid is depend on form of sugar ring become okso or easy reduction form. Reaction of become brown with non enzimatik Maillard that happen in alkali situation is influenced several factors especially temperature and $\mathrm{pH}$. This reaction also produced color and special aroma.

Polysacarida that found in yeast extract is come from fission of cell partition. Main Polysacaride from cell partition is beta 1,3 glucan, mannoproteins with many kitin. Degradation product from Polysacaride is glucose [13].

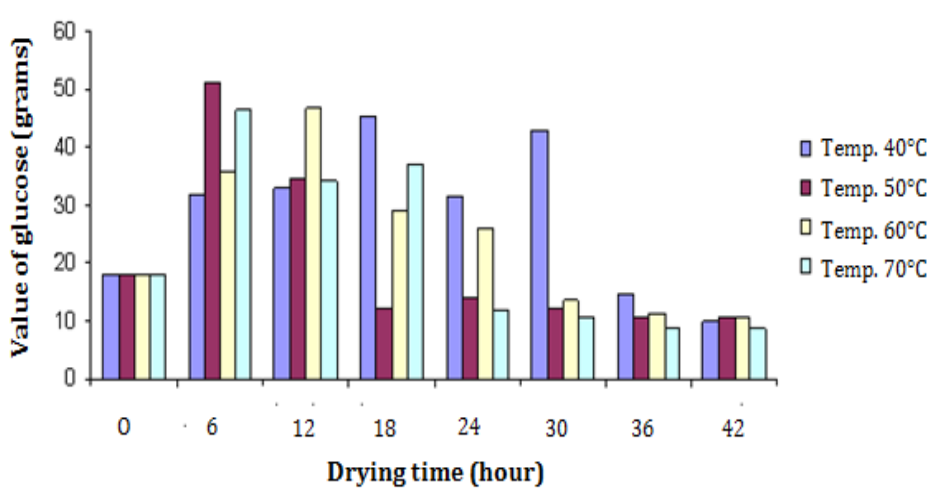

Figure 4. Glucose value at various temperature of oven drying

Vitamin B2 value in yeast extract that dried in all drying temperature experience increase in $6^{\text {th }}$ hour, after that the value is experience decrease until 42 th hour (Figure 5). the damage of vitamin B2 it might be caused of heat and light. Drying process used oven and neutral $\mathrm{pH}$ treatment and a large number of light radiation toward material in the research, also can damage the value of vitamin B2. Riboflavin content is become damage by light very easy, ultraviolet light, heat, and alkali situation, but damage of heat can be protect if the material is in acid situation.

Yeast extract that dried with oven at temperature $40^{\circ} \mathrm{C}$ need drying time during 42 hours until dry, while at temperature $50^{\circ} \mathrm{C}$ need drying time during 30 hours and at temperature $60^{\circ} \mathrm{C}$ and $70^{\circ} \mathrm{C}$ need drying time during 24 hours. Based on result said that the higher of temperature and as long as time that used to dried yeast extract is influence toward damage of yeast extract nutrition. Yeast extract that dried in temperature $60^{\circ} \mathrm{C}$ and $70^{\circ} \mathrm{C}$ during 30 hours have higher nutrient value if compared with dried in temperature $40^{\circ} \mathrm{C}$ during 42 hours. It can be conclude that the many nutrient is damage at drying in low temperature with long time than drying in 
high temperature with short time. It because heat radiation toward material is short so nutrient damage is small, more and more long time of heat radiation toward material so the damage of temperature is more high and long time at producing process will damage the nutrient essence component, such as denaturasi protein, vitamin damage and fat. Thus, it need arrangement of processing temperature so it not damage the nutrient essence [14].

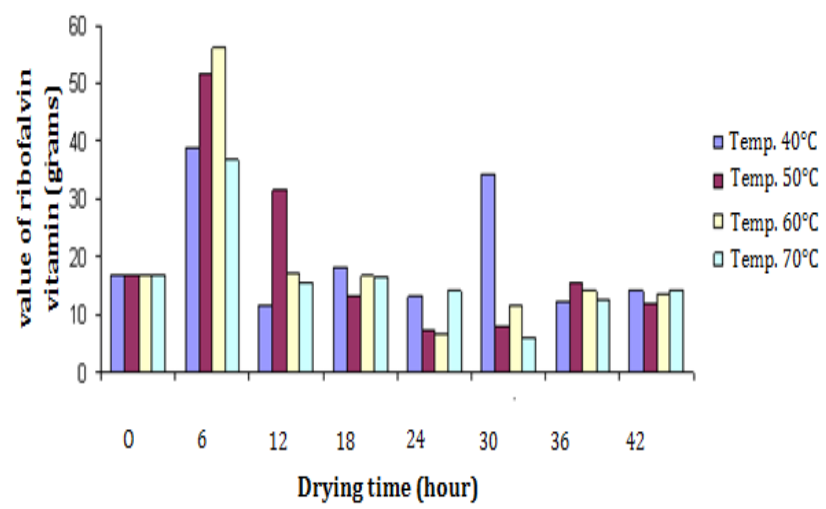

Picture 5. value of ribofalvin vitamin at various temperature of oven drying

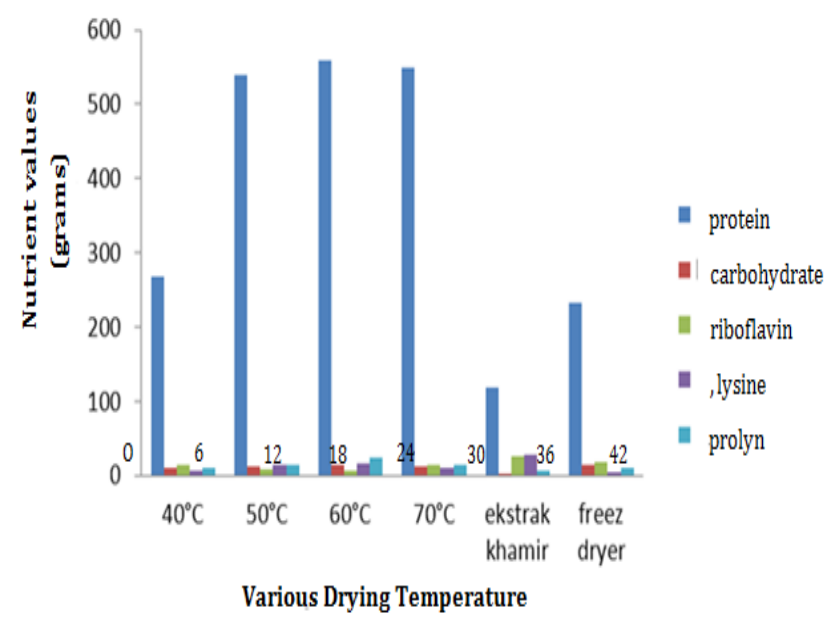

Picture 6. Value of protein, carbohydrate, ribiflavin, lysine, and prolyn at various drying temperature

Based on result, nutrient value at drying used freeze dryer is low that drying used oven, the possibility is caused by the procedure and process of drying used freeze dryer is appropriate with material characteristic so the product is not optimum. It is according to Tambunan [15] drying process used freeze dryer can protect the content of nutrient, shape, color and biology and also product structure, however the superiority from freeze dryer can gain if procedure and process of freeze drying that used is precise and according with characteristic dried material. Certain operational condition which appropriate with a kind of product can not guarantee that it will be appropriate with other product [15].

In drying of yeast extract, drying that less damage the nutrient value is drying used oven at temperature $60^{\circ} \mathrm{C}$ and $70^{\circ} \mathrm{C}$. For the highest value of protein at drying used oven at temperature $60^{\circ} \mathrm{C}$. Generally, at high temperature, protein will experience denaturation [15]. While, in this research, high protein content is gain in high temperature treatment. It is possibility because of material is in dry condition and the water content is un-counted in each drying process.

High carbohydrate value is in drying used freeze dryer. High carbohydrate value at drying freeze dryer because of in low temperature is $0^{\circ} \mathrm{C}$ and pressure 613 pascal [14], so the brown process (maillard) of material can be prohibited. It can be seen at final result of drying process, yeast extract that dried used freeze dryer (Figure 2e) have light color than dried used oven Figure 2a, 2b,c, and 2d).

The high value of vitamin B2 and lysin at yeast extract (MERCK brand). Low value of carbohydrate and lysin at oven drying caused of maillard reaction. Maillard reaction is happen between aldehid cluster from sugar reduction agent with amino cluster from amino acid especially epsilon- 
amino-lisin and alfa-amino asam amino $\mathrm{N}$ terminal. This reaction is impact in descent of availability of lysin and carbohydrate in product of baked product [16].

Based on research result, oven dried at temperature $60^{\circ} \mathrm{C}$ is less damage of yeast extract nutrient. Based on research result, drying process used oven can be alternative of cheap drying process but still keep the nutrient of material.

\section{Conclusion}

Treatment of drying temperature and long time drying process used oven at temperature $40^{\circ} \mathrm{C}, 50^{\circ} \mathrm{C}, 60^{\circ} \mathrm{C}$, and $70^{\circ} \mathrm{C}$ is influence value of nutrient, carbohydrate, and ribovalin vitamin. Nutrient is more damage in drying process at low temperature with long time than in drying process at high temperature with short time. Drying process used oven at temperature $60^{\circ} \mathrm{C}$ is drying process that not damage the nutrient of yeast extract. Based on research result, drying process used oven can be drying process alternative that more cheap but it can keep the nutrient of material.

\section{Acknowledgment}

The authors wish to thank Faculty of Biology, Universitas Kristen Satya Wacana for supporting this work.

\section{References}

[1] S. Marlina, Pemanfaatan Limbah Distilasi Etanol dengan penambahan Effective Microorganism (EM) pada Pertumbuhan Gelombang Cinta (Anthurium plowmanii). TA. FKIP, UMS, Surakarta. Andershon, J. D. (1996). Foundations of Chemistry. $2^{\text {nd }}$ Edition. Wesley Longman Inc., Australia. 2008.

[2] J.B. Helbert, Beer, dalam Reed, G. Presscott and Dunn's. Industrial Microbiology. McGraw Hill. New York, 1982.

[3] J.R.A. Pollock, Brewering Science. Vol I. Academic Press. London, 1979.
[4] G. Reed, and T.W. Naghodawithana, YeastTechnology. $2^{\text {nd }}$ edition, Van Nostrad, Rein Hold. NewYork, 1991.

[5] Anonim. Yeast ekstrack. http://www.eurasyp.org/public.levure.ex trait.screen, 2010.

[6] A.L. Koch, and S.L. Putnam, Sensitive biuret method for determination of protein in an impure system such as whole bacteria. Analytical Biochemistry 44, pp. 239-245, 1971.

[7] Y. Armiya Uji mutu bahan baku Riboflavin sebagai bahan baku vitamin B kompleks yang diproduksi oleh PT Kimia Farma (Persero) Tbk. Plant medium. TA. Univ Sumatera Utara. Medan. 2015.

[8] C.S. James,. Analytical Chemistry of Foods. Blackie Academic \& Professional. London, 1995.

[9] L.S. Bates, R. P. Waldren \& I. D. Tiare (1973). Rapid determination of free proline for water-stress studies. Plant and Soil. 39, 205-207

[10] R.E. Ferrel, D.A. Fellers, A.D. Shepherd, Determination of free lysine and methionine in amino acid fortified wheat. AOCS-AACC Joint Meeting Vol 46, pp. 614620, 1968.

[11] J.D. Andershon, Foundations of Chemistry. $2^{\text {nd }}$ Edition. Wesley Longman Inc., Australia, 1996.

[12] Anonim. Brewer's yeast. http://destiutami.wordpress.com/2007/ 03/07/brewers-yeast/, 2007.

[13] I.S. Mintarti, Ekstraksi Vanili Secara Enzimatik dari Buah Vanili (Vanilla planifolia) Segar. Tesis. IPB. Bogor, 2010.

[14] T. Susanto, dan B. Saneto, Teknologi Pengolahan Hasil Pertanian. Bina Ilmu. Surabaya, 1994.

[15] A.H. Tambunan, dan L.P. Manulu, Mekanisme Pengeringan beku produk Pertanian. Jurnal Sains dan Teknologi Indonesia Vol.2, No.3, pp. 66-74, 2006.

[16] N.S. Palupi, F.R. Zakaria, dan E Prangdimukti, Pengaruh Pengolahan terhadap Nilai Gizi Pangan. Modul eLearning ENBP, Departemen Ilmu \& Teknologi Pangan-Fateta-IPB, 2007. 